Vol. 4, No. 2, Nopember 2018

p-ISSN: 2442-8884 / e-ISSN: 2541-4542

J-Kesmas

Jurnal Kesehatan Masyarakat

\title{
FAKTOR DETERMINAN YANG MEMPENGARUHI TERJADINYA GIZI KURANG PADA BALITA DI KABUPATEN POLEWALI MANDAR
}

\author{
Fredy Akbar K
}

AKPER YPPP Wonomulyo

Email: nursefredy@yahoo.com

\begin{abstract}
ABSTRAK
Status gizi kurang dan gizi buruk memberi konstribusi terhadap angka kematian balita, dimana angka kematian balita (AKABA) yang tertinggi di Indonesia adalah Sulawesi Barat yaitu 96 per 1.000 kelahiran hidup (Kemenkes 2014). Dinas kesehatan Kabupaten Polewali Mandar melaporkan selama tahun 2015 balita yang mengalami gizi kurang sebanyak 1.186 balita kasus pada laki-laki sebanyak 590 balita dan kasus pada perempuan sebanyak 596 balita dan Puskesmas yang paling tinggi angka gizi kurangnya yaitu Puskesmas Pambusuang sebesar 143 balita. Gizi menjadi bagian yang sangat penting dalam pertumbuhan dan perkembangan anak, Apabila seorang anak terkena difisiensi gizi maka kemungkinan besar anak akan mudah terkena infeksi Oleh karena itu diperlukan suatu identifikasi melalui penelitian dengan tujuan untuk mengetahui apakah pendidikan, pemberian makan, dan pendapatan mempengaruhi terjadinya gizi kurang pada balita agar kita dapat keluar dari masalah gizi. Penelitian ini menggunakan metode survey analitik cross sectional. Teknik pengambilan sampel dengan Purposive Sampling yang memenuhi kriteria penelitian sebanyak 80 orang. Hasil penelitian menunjukkan pendidikan rendah berpengaruh terhadap terjadinya gizi kurang dimana nilai $\mathrm{X}^{2}$ hitung $>\mathrm{X}^{2}$ tabel $(4,406>3,841)$, Pemberian makan Ibu yang kurang berpengaruh terhadap terjadinya gizi kurang pada balita hal ini dibuktikan dengan hasil uji statistik nilai $\mathrm{X}^{2}$ hitung $>\mathrm{X}^{2}$ tabel $(21,607>3,841)$, Sedangkan berdasarkan hasil penelitian Pendapatan keluarga tidak berpengaruh terhadap terjadinya gizi kurang pada balita hal ini terlihat dari hasil uji statistik nilai $X^{2}$ hitung $<X^{2}$ tabel $(1,667<3,841)$.
\end{abstract}

Kata kunci: Gizi kurang, Balita

\section{PENDAHULUAN}

Masalah kurang gizi bukanlah

hal yang baru namun masalah ini tetap

aktual terutama di negara-negara

berkembang terutama pada anak balita.

Masalah gizi di Indonesia lebih banyak terjadi pada anak di bawah lima tahun, meskipun selama 10 tahun terakhir terdapat kemajuan dalam penanggulangan masalah gizi di Indonesia. Status gizi masyarakat dapat dinilai dari keadaan gizi balita. Masalah gangguan gizi di Indonesia adalah 4 dari 10 anak balita mengalami gangguan pertumbuhan fisik dan tingkat kecerdasan disebabkan karena penyakit 
Vol. 4, No. 2, Nopember 2018

p-ISSN: 2442-8884 / e-ISSN: 2541-4542

J-Kesmas

Jurnal Kesehatan Masyarakat

kekuarangan gizi berupa Kurang Energi

Protein (KEP) (Aritonang 2005).

Masalah gizi pada hakikatnya adalah masalah kesehatan masyarakat, namun penanggulangannya tidak dapat dilakukan dengan pendekatan medis dan pelayanan kesehatan saja. Penyebab timbulnya masalah gizi multifaktor, oleh karena itu pendekatan penanggulangannya harus melibatkan berbagai sektor yang terkait (Depkes, 2007).

Status gizi terdiri dari status gizi buruk, kurang, baik dan lebih. Status gizi baik atau status gizi optimal terjadi bila tubuh memperoleh cukup zat-zat yang digunakan secara efesien, sehingga memungkinkan pertumbuhan fisik, perkembangan otak, kemampuan kerja dan kesehatan secara umum. Status gizi kurang terjadi bila jumlah asupan zat gizi kurang dari yang dibutuhkan sebaliknya status gizi lebih terjadi bila jumlah asupan gizi melebihi dari yang dibutuhkan (Proverawati, 2009).

Kurang gizi pada masa balita dapat menimbulkan gangguan tumbuh kembang secara fisik, mental, sosial, dan intelektual yang sifatnya menetap dan terus dibawa sampai anak menjadi dewasa. Secara lebih spesifik,

kekurangan gizi dapat menyebabkan keterlambatan pertumbuhan badan, lebih penting lagi keterlambatan perkembangan otak, dan dapat pula terjadinya penurunan atau rendahnya daya tahan tubuh terhadap penyakit infeksi (Supariasa, 2002).

Masalah gizi muncul akibat masalah ketahanan pangan ditingkat rumah tangga. Dalam konteks ini masalah gizi tidak lagi semata-mata masalah kesehatan tetapi juga masalah kemiskinan, pemerataan, dan masalah kesempatan kerja. Di Indonesia dan negara berkembang, masalah gizi pada umumnya masih didominasi oleh masalah Kurang Energi Protein (KEP), Anemia Gizi Besi (AGB), Gangguan Kekurangan Yodium (GAKY), dan Kurang Vitamin A (KVA). Status gizi kurang dan gizi buruk memberi konstribusi terhadap angka kematian balita, dimana Angka Kematian Balita (AKABA) yang tertinggi di Indonesia adalah Sulawesi Barat yaitu 96 per 1.000 kelahiran hidup (Depkes, 2009).

Dinas kesehatan kabupaten Polewali Mandar melaporkan selama tahun 2015 balita yang mengalami gizi kurang sebanyak 1.186 balita kasus pada laki-laki sebanyak 590 balita dan kasus pada perempuan sebanyak 596 
Vol. 4, No. 2, Nopember 2018

p-ISSN: 2442-8884 / e-ISSN: 2541-4542

J-Kesmas

Jurnal Kesehatan Masyarakat

balita dan Puskesmas yang paling tinggi

angka gizi kurangnya yaitu Puskesmas

Pambusuang sebesar 143 balita

(12,05\%). (Dinkes Sulbar, 2015)

Salah satu upaya yang dilakukan pemerintah dalam menanggulangi gizi kurang dan gizi buruk pada balita yaitu dengan mencanangkan rencana aksi kabupaten dalam pencegahan dan penanggulangan gizi buruk yang merupakan prioritas pembangunan pada Rencana Pembangunan Jangka Menengah Daerah (RPJMD) kabupaten Polewali Mandar dan upaya meningkatkan cakupan deteksi dini gizi kurang dan gizi buruk melalui penimbangan bulanan balita di Posyandu, meningkatkan cakupan dan kualitas tatalaksana status gizi buruk di Puskesmas, Rumah sakit dan rumah tangga, menyediakan Pemberian Makanan Tambahan Pemulihan (PMTP) kepada balita gizi kurang dan gizi buruk, meningkatkan pengetahuan dan keterampilan ibu dalam memberikan asupan gizi pada anak (ASI/MP-ASI), Serta memberikan suplementasi gizi berupa kapsul vitamin A kepada semua balita (BAPPEDA Polman, 2015).

Pemerintah Indonesia serius untuk mengurangi angka kurang gizi. Faktanya, stunting pada balita adalah

salah satu dari indikator pembangunan dalam Rencana Pembangunan Jangka Menengah Nasional (RPJMN) untuk tahun 2015-2019. Pemerintah Indonesia menyadari bahwa mereka tidak dapat mencapai hasil ini tanpa adanya upaya bersama dari seluruh pemangku kepentingan termasuk seluruh rumah tangga dan masyarakat.

\section{METODE PENELITIAN}

\section{Jenis dan Metode Penelitian}

Jenis penelitian yang digunakan adalah survey analitik dengan pendekatan cross sectional dimana variable independen dan variable dependen diobservasi sekaligus pada waktu yang sama, menggunakan metode survey analitik Cross Sectional. Besar sampel sebanyak 80 Balita, didapatkan dengan menggunakan rumus lemeshow, Dan teknik pengambilan sampel dengan Purposive Sampling yang memenuhi kriteria penelitian

\section{Lokasi dan Waktu Penelitian}

Penelitian dilaksanakan di puskesmas Batupanga Kecamatan Luyo Dan Pusakesmas Limboro Kecamatan Limboro Kabupaten Polewali Mandar pada bulan Juni sampai Agustus 2018.

\section{Populasi dan Sampel}


Vol. 4, No. 2, Nopember 2018

J-Kesmas

Jurnal Kesehatan Masyarakat

Populasi dalam penelitian ini

adalah semua balita yang ada di

Wilayah kerja Puskesmas Batupanga

dan Puskesmas Limboro sebanyak 6014

dan sampel yang diambil adalah semua

balita (6 bln $-<60$ bln) yang datang

berkunjung serta dilayani pada saat

kegiatan Posyandu.

\section{Cara Pengumpulan Data}

Dilakukan dengan cara wawancara langsung dengan ibunya serta mengisi kusioner yang dipersiapkan dan dengan penimbangan, Sampel yang akan diambil melalui pertimbangan-pertimbangan.

\section{Langkah Pengelolaan Data}

Setelah data terkumpul, dilanjutkan dengan pengolohan data secara manual, data yang diperoleh dari penelitian diolah secara deskriptif sederhana dengan menggunakan uji statistic untuk mengetahui distribusi, frekuensi.persentase dan disajikan dalam bentuk naskah .

\section{HASIL DAN PEMBAHASAN}

\section{Hasil Penelitian}

A. Data Demografi

\section{Karakteristik Responden}

1. Status Gizi Balita

Tabel 1

Karakteristik Responden Berdasarkan Status Gizi Balita

\begin{tabular}{ccc}
\hline Status Gizi & F & \% \\
\hline Gizi baik & 45 & 50 \\
Gizi kurang & 45 & 50 \\
\hline Total & $\mathbf{9 0}$ & $\mathbf{1 0 0 \%}$ \\
\hline
\end{tabular}

Sumber : Data Primer

Tabel diatas menggambarkan bahwa dari 90 balita yang ditimbang 45 orang $(50 \%)$ mempunyai status gizi yang baik dan 45 orang (50\%) mempunyai status gizi kurang.

2. Pendidikan Ibu

Tabel 2

Karakteristik Responden Berdasarkan Pendidikan Ibu Balita

\begin{tabular}{llc}
\hline $\begin{array}{c}\text { Tingkat } \\
\text { pendidikan }\end{array}$ & F & \% \\
\hline Tinggi & 13 & 14,4 \\
Rendah & 77 & 85,6 \\
\hline Total & $\mathbf{9 0}$ & $\mathbf{1 0 0 \%}$ \\
\hline Sumber : Data Primer & & \\
Berdasarkan tabel 2 & diatas \\
menunjukkan bahwa & responden yang & yong \\
tingkat pendidikannya tinggi 13 & orang \\
$(14,4 \%)$ lebih kecil dibandingkan & dingkat \\
dengan responden yang & tingk \\
pendidikannya rendah 77 & orang \\
$(85,6 \%)$. &
\end{tabular}

3. Pemberian makanan

Tabel 3

Karakteristik Responden Berdasarkan Pemberian makanan pada Balita 
Vol. 4, No. 2, Nopember 2018

J-Kesmas

Jurnal Kesehatan Masyarakat

Sumber : Data Primer

Berdasarkan tabel diatas

menunjukkan bahwa responden yang memberikan makanan yang cukup 48 orang $(53,3 \%)$ sedangkan yang kurang 42 orang $(46,7 \%)$.

4. Pendapatan Keluarga

Tabel 4

Karakteristik Responden Berdasarkan Pendapatan Keluarga Balita

\begin{tabular}{ccc}
\hline Pendapatan & F & $\%$ \\
\hline Cukup & 54 & 60 \\
Kurang & 36 & 40 \\
Total & $\mathbf{9 0}$ & $\mathbf{1 0 0}$ \\
\hline
\end{tabular}

Sumber : Data Primer

Berdasarkan tabel diatas menunjukkan bahwa pendapatan keluarga balita yang kurang sebanyak 36 orang $(40 \%)$ dan pendapatan keluarga yang cukup 54 orang (60\%).

\section{Analisis Pengaruh Variabel}

\section{Penelitian}

Sesuai dengan tujuan yang ingin dicapai dalam penelitian ini, adalah untuk mengetahui dinamika pengaruh antara faktor risiko yang merupakan variabel independen dengan efek atau akibat yang merupakan variabel dependen, maka analisis dilanjutkan dengan pengujian hipotesis yang dapat dilhat pada uraian berikut:

\begin{tabular}{ccc}
\hline $\begin{array}{c}\text { Pemberian } \\
\text { makanan }\end{array}$ & F & \% \\
\hline Cukup & 48 & 53,3 \\
Kurang & 42 & 46,7 \\
\hline Total & $\mathbf{9 0}$ & $\mathbf{1 0 0}$ \\
\hline $\begin{array}{l}\text { 1. Pengaruh tingkat pendidikan } \\
\text { dengan Status gizi }\end{array}$ & Balita &
\end{tabular}

Tabel 5

Analisis pengaruh Tingkat Pendidikan ibu Dengan Status Gizi Balita

\begin{tabular}{|c|c|c|c|c|c|c|c|}
\hline \multirow{3}{*}{$\begin{array}{c}\text { Pendidi } \\
\text { kan } \\
\text { Ibu }\end{array}$} & \multicolumn{4}{|c|}{ Status Gizi } & \multicolumn{2}{|c|}{ Total } & \multirow{3}{*}{$\begin{array}{c}\mathrm{X}^{2} / \mathrm{P} \\
(95 \%, \mathrm{C} \\
)\end{array}$} \\
\hline & \multicolumn{2}{|c|}{ Baik } & \multicolumn{2}{|c|}{ Kurang } & & \\
\hline & $\mathbf{N}$ & $\%$ & $\mathbf{N}$ & $\%$ & $\mathbf{N}$ & $\%$ & \\
\hline & 3 & 3, & 10 & 11 & 13 & 14 & $X^{2}=4,40$ \\
\hline Rendah & 42 & 46,7 & 35 & 38,9 & 77 & 85,6 & $\begin{array}{c}6 \mathrm{P} \\
=0,069\end{array}$ \\
\hline
\end{tabular}

\begin{tabular}{lllllll} 
Total & 45 & 50 & 45 & 50 & 90 & 100 \\
\hline
\end{tabular}

Sumber : Data Primer

Tabel diatas memperlihatkan bahwa dari 90 responden yang menjadi sampel, Ibu yang berpendidikan rendah dengan balita berstatus gizi kurang sebanyak 35 atau 38,9\%, tidak berbeda jauh dengan Ibu yang berpendidikan rendah dengan balita berstatus gizi baik yaitu sebanyak 42 orang atau $46,7 \%$

Hasil analisis pengaruh melalui uji statistik "chi square" pada tingkat kepercayaan 0,95 dengan tingkat kemaknaan $(\alpha)=0,05$ dan $\mathrm{df}=1$, Didapatkan nilai $X^{2}$ hitung $>X^{2}$ tabel $(4,406>3,841)$.

\section{Pengaruh pemberian makanan dengan Status Gizi Balita}

Tabel 6 
Vol. 4, No. 2, Nopember 2018

J-Kesmas

Jurnal Kesehatan Masyarakat

Analisis Pengaruh Pemberian Makanan

Dengan Status Gizi Balita

\begin{tabular}{|c|c|c|c|c|c|c|c|}
\hline \multirow{3}{*}{$\begin{array}{l}\text { Pemberian } \\
\text { makanan }\end{array}$} & \multicolumn{4}{|c|}{ Status Gizi } & \multirow{2}{*}{\multicolumn{2}{|c|}{$\begin{array}{c}\text { Total } \\
\%\end{array}$}} & \multirow{3}{*}{$\begin{array}{c}\mathrm{X}^{2} / \mathrm{p} \\
(95 \%, \mathrm{CI})\end{array}$} \\
\hline & \multicolumn{2}{|c|}{ Baik } & \multicolumn{2}{|c|}{ Kurang } & & & \\
\hline & $\mathrm{n}$ & $\%$ & $\mathrm{~N}$ & $\%$ & $\mathrm{~N}$ & $\%$ & \\
\hline Cukup & 13 & 14,4 & 35 & 38,9 & 48 & 53,3 & $\mathrm{X}^{2}=21,6$ \\
\hline Kurang & 32 & 35,6 & 10 & 11,1 & 42 & 46,7 & $7 \mathrm{P}=0,00$ \\
\hline Total & 45 & 50 & 45 & 50 & 90 & 100 & \\
\hline
\end{tabular}

Sumber : data Primer

Tabel diatas memperlihatkan bahwa dari 90 responden yang menjadi sampel, pemberian makan Ibu yang kurang dengan balita berstatus gizi kurang sebanyak 10 orang atau $11,1 \%$, lebih kecil dibandingkan pemberian makan Ibu yang kurang dengan balita berstatus gizi baik yaitu sebanyak 32 orang atau $35,6 \%$.

Hasil analisis pengaruh melalui uji statistik "chi square" pada tingkat kepercayaan 0,95 dengan tingkat kemaknaan $(\alpha)=0,05$ dan $\mathrm{df}=1$, didapatkan nilai $\mathrm{X}^{2}$ hitung $>\mathrm{X}^{2}$ tabel $(21,607>3,841)$

\section{Pengaruh Tingkat Pendapatan dengan status gizi Balita}

Tabel 7

Analisis Pengaruh Pendapatan Keluarga Dengan Status Gizi Balita
p-ISSN: 2442-8884 / e-ISSN: 2541-4542

\begin{tabular}{|c|c|c|c|c|c|c|c|}
\hline \multirow{3}{*}{$\begin{array}{l}\text { Pendapatan } \\
\text { Keluarga }\end{array}$} & \multicolumn{4}{|c|}{ Status Gizi } & \multicolumn{2}{|c|}{ Total } & \multirow{3}{*}{$\begin{array}{c}\mathbf{x}^{2} / \mathbf{p} \\
(95 \%, \mathrm{CI})\end{array}$} \\
\hline & \multicolumn{2}{|c|}{ Baik } & \multicolumn{2}{|c|}{ Kurang } & \multirow[b]{2}{*}{$\mathbf{N}$} & \multirow[b]{2}{*}{$\%$} & \\
\hline & $\mathbf{n}$ & $\%$ & $\mathbf{n}$ & $\%$ & & & \\
\hline Cukup & 24 & 26,7 & 30 & 33,3 & 54 & 60 & \\
\hline Kurang & 21 & 23,3 & 15 & 16,7 & 36 & 40 & $\begin{array}{l}X^{2}=1,667 \\
P=0,282\end{array}$ \\
\hline Total & 45 & 50 & 45 & 50 & 90 & 100 & \\
\hline
\end{tabular}

Sumber : Data Primer

Tabel diatas memperlihatkan bahwa dari 90 responden yang menjadi sampel, keluarga berpendapatan kurang dengan balita berstatus gizi kurang sebanyak 15 atau $16,7 \%$, tidak berbeda jauh dengan keluarga yang berpendapatan kurang dengan balita berstatus gizi baik yaitu 21 orang atau $23,3 \%$.

Hasil analisis pengaruh melalui uji statistik "chi square" pada tingkat kepercayaan 0,95 dengan tingkat kemaknaan $(\alpha)=0,05$ dan $\mathrm{df}=1$, didapatkan nilai $\mathrm{X}^{2}$ hitung $<\mathrm{X}^{2}$ tabel $(1,667<3,841)$.

\section{PEMBAHASAN}

1. Pengaruh pendidikan ibu dengan status gizi balita

Dictionary of Education menyebutkan bahwa pendidikan adalah proses dimana seseorang mengembangkan kemampuan sikap dan bentuk-bentuk tingkah laku lainnya 
Vol. 4, No. 2, Nopember 2018

p-ISSN: 2442-8884 / e-ISSN: 2541-4542

J-Kesmas

Jurnal Kesehatan Masyarakat

didalam masyarakat dimana ia hidup, proses sosial dimana orang dihadapkan pada pengaruh lingkungan yang terpilih dan terkontrol (khususnya yang datang dari sekolah) sehingga dia dapat memperoleh atau mengalami perkembangan kemampuan sosial dan kemampuan individu yang optimum.

Pendidikan ibu merupakan hal penting dalam hubungannya dengan status gizi, bahwa semakin tinggi tingkat pendidikan seseorang maka akan menambah kemampuan berpikir untuk menyerap informasi dan menggunakan secara tepat didalam pengambilan keputusan yang berhubungan dengan status gizi (Ahmad, 2007).

Tabel 6 memperlihatkan bahwa dari 100 responden yang menjadi sampel, Ibu yang berpendidikan rendah dengan balita berstatus gizi kurang tidak berbeda jauh dengan Ibu yang berpendidikan rendah dengan balita berstatus gizi baik yaitu hanya selisih 7 orang.

Dan dari hasil uji statistik diperoleh nilai $\mathrm{X}^{2}$ hitung $>\mathrm{X}^{2}$ tabel $(4,406>3,841)$ dengan nilai rentang 0,56 antara $X^{2}$ hitung dengan $X^{2}$ tabel walaupun secara logika dan teori selisih yang tidak terlalu jauh tidak

memberikan pengaruh yang bermakna namun selisih yang sekecil apapun akan memberikan pengaruh yang bermakna bila diuji dengan statistik, dengan demikian berdasarkan dari hasil analisis tersebut, ada pengaruh positif dan signifikan antara pendidikan ibu yang rendah dengan status gizi kurang pada balita.

2. Pengaruh pemberian makanan ibu dengan status gizi balita

Pemberian makanan adalah membagikan atau menyampaikan bahan selain obat yang mengandung zat- zat gizi dan unsur-unsur ikatan kimia yang dapat diubah menjadi zat gizi oleh tubuh yang berguna bila dimasukkan dalam tubuh. Anak mendapat cukup makanan tetapi sering menderita sakit karna ketidak cukupan nilai gizi pada makanan yang dikomsumsinya pada akhirnya dapat menderita gizi kurang. Komsumsi zat gizi keluarga dipengaruhi oleh berbagai faktor diantaranya adalah: Pemilihan bahan makanan, Pengolahan, Pengelolaan, Komposisi makanan, Jenis-jenis makanan, Penyajian, Frekwensi pemberian makanan, serta pola distribusi makanan dalam keluarga yang tidak merata dan sering mendahulukan anggota keluarga 
Vol. 4, No. 2, Nopember 2018

p-ISSN: 2442-8884 / e-ISSN: 2541-4542

J-Kesmas

Jurnal Kesehatan Masyarakat

tertentu sehingga anaknya selalu

Pendapatan keluarga adalah mengkomsumsi makanan yang miskin zat gizi (Siswono, 2009)

Pemberian makanan merupakan salah satu upaya yang berkaitan dengan pengaturan pola konsumsi makanan keluarga terutama bagi anak-anaknya yang berumur dibawah lima tahun (balita).

Pada tabel 6 memperlihatkan bahwa dari 100 responden yang menjadi sampel, Ibu dengan pemberian makan yang kurang dengan balita berstatus gizi kurang dengan Ibu yang pemberian makan kurang dengan balita berstatus gizi baik yaitu hanya selisih 21 orang

Dan dari hasil uji statistik diperoleh nilai $\mathrm{X}^{2}$ hitung $>\mathrm{X}^{2}$ tabel $(21,607>3,841)$, dengan nilai rentang antara $X^{2}$ hitung dengan $X^{2}$ tabel sebesar 17,76. Secara logika dan teori selisih yang tidak terlalu jauh tidak memberikan pengaruh yang bermakna namun selisih yang sekecil apapun akan memberikan pengaruh yang bermakna bila diuji dengan statistik, dengan demikian ada pengaruh positif dan signifikan antara pemberian makan ibu yang kurang dengan status gizi kurang pada balita.

3. Pengaruh pendapatan keluarga dengan status gizi balita 
Vol. 4, No. 2, Nopember 2018

p-ISSN: 2442-8884 / e-ISSN: 2541-4542

J-Kesmas

Jurnal Kesehatan Masyarakat

ada pengaruh positif dan signifikan

antara pendapatan keluarga yang kurang dengan status gizi kurang pada balita.

Walaupun tidak dapat disangkal bahwa keterbatasan penghasilan keluarga akan turut menentukan hidangan yang disajikan untuk keluarga sehari-hari, Baik kualitas maupun kuantitas makanan, Pendapatan akan menentukan daya beli terhadap pangan dan fasilitas lain seperti pendidikan, perumahan, kesehatan, dll yang dapat mempengaruhi status gizi.

Pendapatan merupakan faktor determinan utama dalam komsumsi makanan. Dengan demikian secara teori jelas ada pengaruh antara pendapatan keluarga dengan status gizi balita . Namun hasil penelitian di lapangan tidak sesuai dengan teori tersebut, hal ini disebabkan karena adanya faktor lain yang mempengaruhi terjadinya gizi kurang, seperti pola asuh dimana hampir semua ibu balita yang berkunjung ke posyandu memiliki anak balita 2 bahkan lebih dengan jarak kelahiran yang tidak terlalu jauh sehingga menyebabkan ibu kurang memperhatikan balitanya, Begitu juga dengan penyakit infeksi dan sanitasi lingkungan yang ada didaerah tersebut mungkin lebih berpengaruh, dimana 
Vol. 4, No. 2, Nopember 2018

J-Kesmas

Jurnal Kesehatan Masyarakat

serta pengujian statistik, maka dapat

disimpulkan sebagai berikut :

1. Ada pengaruh antara pendidikan ibu dengan terjadinya gizi kurang pada balita.

2. Ada pengaruh antara pemberian makanan ibu dengan terjadinya gizi kurang pada balita

3. Tidak ada pengaruh antara pendapatan ibu dengan terjadinya gizi kurang pada balita

\section{Saran}

1. Puskesmas Batupanga perlu melakukan suatu intervensi gerakan upaya peduli gizi seperti program Bina Keluarga Balita (BKB) yang dapat dilakukan melalui penyuluhan tentang gizi secara berkesinambungan terutama kepada ibu balita untuk lebih meningkatkan pengetahuannya agar pengetahuan ibu tentang makanan seimbang dapat bertambah, Dengan melibatkan lintas program dan lintas sektoral.

2. Keluarga perlu memperhatikan asupan gizi balitanya agar makanan yang dikomsumsi dapat memenuhi tingkat kecukupan zat gizi sesuai dengan kebutuhanya.

3. Disarankan kepada Dinas kesehatan agar upaya pencegahan terhadap gizi
p-ISSN: 2442-8884 / e-ISSN: 2541-4542

kurang mendapat prioritas seperti pemberian makanan tambahan (PMT), sebaiknya sesuai dengan jumlah kebutuhan anak agar status gizi anak semakin baik dan tidak bertambah buruk.

\section{DAFTAR PUSTAKA}

Aritonang 2005. Pemantauan Pertumbuhan Balita (Petunjuk Praktis Menilai Status Gizi dan Kesehatan). Yogyakarta

Bulechek, M. (1996). Nursing Intervention Clasification. Edisi e. St Louis: Mosby Year Book Inc.

Crisp, J. \& Taylor C. (2001). Potter \& Perry Fundamental of nursing. Australia: Harcourt.

Depkes RI, 2013, Info Pangan dan Gizi, Ditjen Pembinaan Kesehatan Masyarakat Direktorat Bina Gizi Masyarakat, Jakarta.

Depkes RI 2006, Petunjuk Tehnis Tatalaksana Anak Gizi Buruk Buku II, Direktorat Jenderal Kesehatan Masyarakat, Direktorat Gizi Masyarakat,Jakarta.

Departemen Gizi dan Kesehatan Masyarakat FKM UI,2012,Masyarakat,Gizi dan Kesehatan Cetakan Pertama, Penerbit PT Raja Grafindo Persada, Jakarta.

Dinas Kesehatan POLMAN 2014,Profil Kesehatan Kabupaten Polewali Mandar 2013, Dinas Kesehatan Kabupaten Polewali Mandar

Dinas Kes Sulbar 2013,Profil Kesehatan Profinsi Sulawesi Barat 
Vol. 4, No. 2, Nopember 2018

$\mathrm{J}$-Kesmas

Jurnal Kesehatan Masyarakat

2007, Dinas Kesehatan Sulawesi

Barat.

Grodner, M., Long, S., and Walkingshaw, B. (2007).

Foundations and Clinical Applications of Nutrition. Fourth edition. St. Louis: Mosby.Inc

Hidayat Alimul ,A Azis 2003, Metode Penelitian Keperawatanan dan Tehnik Analisa Data,Salemba,Medika,Jakarta.

Notoatmojo S, 2005, Metodologi Penelitian Kesehatan,Cetakan III, Rineke Cipta,Jakarta.

Siswono. 2009. Gizi buruk aib negara berkembang.

http://www.gizi.net/cgi- bin/berita /fullnews.cgi?newsid1240297552,7 3711. diambil pada 06 Januari 2013

Supariasa, Bachyar Bakri \& Ibnu Fajar (2002) Penilaian Status Gizi, Jakarta:EGC.

Wiwan,A.K.2008. Gizi Buruk Statistik atau Empirik. http :// theindonesianinstiutute.com /index.php/200841616163/Gizi-

Buruk Statistik-atau-Empirik.html. Diambil pada 12 Agustus 2014 